\title{
Prediksi Masa Studi Mahasiswa dengan Menggunakan Algoritma Naïve Bayes
}

\author{
Mongan Winny Amelia, Arie S. M. Lumenta, Agustinus Jacobus \\ Teknik Informatika Universitas Sam Ratulangi \\ 120216039@student.unsrat.ac.id, al@unsrat.ac.id, a.jacobus@unsrat.ac.id
}

\begin{abstract}
Abstrak - Data mining adalah teknik yang memanfaatkan data dalam jumlah yang besar untuk memperoleh informasi berharga yang dapat dimanfaatkan untuk pengambilan keputusan penting. Data kelulusan mahasiswa Universitas Sam Ratulangi menghasilkan data akademik mahasiswa yang berpengaruh pada kualitas perguruan tinggi lewat akreditas yang dilaksanakan oleh Badan Akreditasi Nasional atau BAN-PT. Nä̈ve Bayes merupakan algoritma yang dapat digunakan untuk prediksi masa studi mahasiswa yang bisa dikategorikan tepat waktu, terlambat dan tidak lulus. Dengan menggunakan data mining khususnya klasifikasi untuk prediksi dengan algoritma naïve bayes dapat dilakukan prediksi terhadap ketepatan waktu studi dari mahasiswa berdasarkan data training yang ada.. Pengujian yang dipakai yaitu $k$-fold cross validation 10-fold. Hasil pengujian didapat nilai akurasi rata-rata sebesar 85.17 $\%$ sedangkan nilai akurasi tertinggi sebesar $88.96 \%$.
\end{abstract}

Kata kunci : Nä̈ve Bayes, K-Fold Cross Validation, Data Mining, Prediksi.

\section{PENDAhuluan}

Banyak data yang dapat dijadikan informasi untuk memustuskan tindakan atau aktivitas masyarakat sehari hari. Informasi dari suatu data saja tidak cukup untuk dijadikan suatu keputusan. Dalam hal ini suatu Universitas dapat menggunakan data yang telah diolah menjadi informasi, seperti data mahasiswa, data pegawai, data dosen, data prestasi mahasiswa data jumlah kelulusan mahasiswa tiap tahun serta data lainnya. Penggunaan data mining dapat digunakan sebagai pertimbangan dalam mengambil keputusan lebih lanjut tentang faktor yang mempengaruhi kelulusan khususnya faktor dalam data induk mahasiswa. Tingkat kelulusan mahasiswa berpengaruh terhadap akreditasi Universitas.

Dalam jenjang pendidikan Program Sarjana (S1) di Fakultas Teknik memiliki beban 144 sks (satuan kredit semester) yang harus diselaikan dalam waktu delapan semester. Masing-masing mahasiswa memiliki pengontrakan jumlah dan jenis mata kuliah yang berbeda di setiap semester yang membuat juga nilai IP semester berbeda - beda. Nilai IP semester juga sangat berpengaruh terhadapat IPK mahasiswa. Tahun lulus mahasiswa dipengaruhi oleh nilai IPK serta waktu pengontrakan setiap Mata Kuliah yang diambil.

Berdasarkan hal diatas, maka perlu dibuat implementasi data mining dengan suatu algoritma untuk memprediksi lama masa studi mahasiswa, yang mempunyai kemampuan melihat pola kelulusan mahasiswa, untuk selanjutnya bisa menjadi strategi dalam proses perkuliahan. Informasi lama masa studi dari mahasiswa Universitas Sam Ratulangi sangat penting untuk meningkatkan pelayanan yang dapat membuat mahasiswa nyaman dan bisa lulus tepat waktu. Pada penelitian yang akan dilakukan ini, menjelaskan bahwa faktor yang paling berpengaruh dalam tingkat kelulusan mahasiswa adalah Indeks Prestasi Semester (IPS) dan Jumlah Sistem Kredit Semester (SKS) secara keseluruhan maupun tiap semester.

\section{LANDASAN TEORI}

A. Data Mining

Data mining adalah istilah yang digunakan untuk mendapatkan penemuan pengetahuan dan atau informasi di dalam database. Menurut Gartner Group data mining adalah suatu proses menemukan hubungan yang berarti, pola, dan kecenderungan dengan memeriksa dalam sekumpulan data yang tersimpan dalam penyimpanan dengan menggunakan teknik statistik dan matematika [1].

Menurut [2], tujuan dari adanya data mining adalah:

1. Explanatory, yaitu untuk menjelaskan beberapa kegiatan observasi atau suatu kondisi

2. Confirmatory, yaitu untuk mengkonfirmasi suatu hipotesis yang telah ada.

3. Exploratory, yaitu untuk menganalisis data baru suatu relasi yang janggal

Data mining memiliki banyak fungsi yang dapat digunakan. Fungsi data mning dapat digabungkan dalam kasus tertentu untuk menjawab masalah yang ada [3]. Berikut adalah fungsi data mining secara umum :

1. Classification

Fungsi dari Classification adalah untuk mengklasifikasi suatu target class ke dalam kategori yang dipilih.

2. Clustering

Fungsi dari clustering adalah untuk mencari pengelompokan atribut ke dalam segmentasisegmentasi berdasarkan similaritas.

\section{Association}

Fungsi dari association adalah untuk mencari keterkaitan antara atriut atau item set, berdasarkan jumlah item yang muncul dan rule association yang ada.

\section{Regression}

Fungsi dari regression hamper mirip dengan klasifikasi. Fungsi dari regression adalah bertujuan untuk mencari prediksi dari suatu pola yang ada.

\section{Forecasting}

Fungsi dari forecasting adalah untuk peramalan waktu yang akan datang berdasarkan trend yang telah terjadi di waktu sebelumnya.

\section{Sequence Analysis}

Fungsi dari sequence analysis adalah untuk mencari pola urutan dari rangkaian kejadian. 


\section{E-Journal Teknik Informatika Vol 11, No.1 (2017) ISSN : 2301 - 8364}

\section{Deviation Analysis}

Fungsi dari devation analysis adalah untuk mencari kejadian langka yang sangat berbeda dari keadaan normal (kejadian abnormal).

B. Klasifikasi

Dalam klasifikasi ada dua pekerjaan utama yang dilakukan, yaitu : pertama, pembangunan model sebagai prototype untuk disimpan sebagai memori dan kedua, penggunaan model tersebut untuk melakukan pengenalan/klasifikasi/prediksi pada suatu objek data lain agar diketahui di kelas mana objek data tersebut dalam model yang mudah disimpan [4].

Proses untuk menemukan pola yang menjelaskan data yang penting dikenal sebagai klasifikasi. Metode klasifikasi dalam data mining ada banyak, diantaranya decision tree, k-nearest neighbor, neural network dan naïve bayes.

1. Decision Tree

Decision Tree merupakan metode klasifikasi dalam bentuk diagram yang direpresentasikan seperti struktur pohon.

\section{K-Nearest Neighbor}

Metode K-Nearest Neighbor merupakan metode klasifikasi pertama yang dijabarkan pada awal tahun 1950 .

3. Neuwal Network

Neural Network terinspirasi oleh pengenalan sistem pembelajaran yang kompleks pada otak binatang yang terdiri atas kumpulan neuron yang saling berhubungan.

4. Nä̈ve Bayes

Klasifikasi naïve bayes adalah salah satu teknik data mining yang paling popular untuk mengklasifikasikan data dalam jumlah besar dan dapat digunakan untuk memprediksi probabilitas keanggotaan suatu class.

\section{Nä̈ve Bayes}

Naive Bayes merupakan teknik prediksi berbasis probabilistik sederhana yang berdasar pada penerapan teorema Bayes (aturan Bayes) dengan asumsi independensi (ketidaktergantungan) yang kuat (naif). Dengan kata lain, dalam Naive Bayes model yang digunakan adalah "model fitur independen" [4]

$$
\operatorname{Probabilitas}(H \mid E, e)=p(H \mid E) * \frac{p(e \mid E, H)}{p(e, E)}
$$

Dimana :

\begin{tabular}{|c|c|}
\hline $\mathrm{E}$ & $=$ evidence \\
\hline $\mathrm{E}$ & $=$ evidence obeservasi baru \\
\hline $\mathrm{P}(\mathrm{H} \mid \mathrm{E}, \mathrm{e})$ & $\begin{aligned}= & \text { probabilitas hitosesis } \mathrm{H} \text { benar jika } \\
& \text { muncul evidence baru daru } \mathrm{E} \text { dari } \\
& \text { evidence e }\end{aligned}$ \\
\hline $\mathrm{p}(\mathrm{H} \mid \mathrm{E})$ & $\begin{aligned}= & \text { probabilitas hitosesis } \mathrm{H} \text { benar jika } \\
& \text { diberikan evidence } \mathrm{E}\end{aligned}$ \\
\hline $\mathrm{p}(\mathrm{e} \mid \mathrm{E}, \mathrm{H})$ & $=$ kaitan antara e dan $\mathrm{E}$ jika $\mathrm{H}$ benar \\
\hline $\mathrm{p}(\mathrm{e} \mid \mathrm{E})$ & $\begin{array}{l}=\text { kaitan tanpa memandang hipotesis } \\
\text { apapun }\end{array}$ \\
\hline
\end{tabular}

D. Tahapan Data Mining

1. Data Selection

Data selection adalah pemilihan data yang relevan dengan tugas analisis diambil dari database.
Data selection merupakan pemilihan himpunan data atau seleksi data dari sekumpulan data. Proses seleksi perlu dilakukan sebelum tahap penggalian informasi dimulai. Data hasil seleksi akan digunakan untuk proses data mining, disimpan terpisah dengan basis data operasional.

\section{Preprocessing}

Preprocessing merupakan tahapan awal dalam pengolahan data .beberapa kasus pasti memiliki kualitas data yang kurang baik. Data yang memiliki kualitas data yang kurang baik memiliki kekurangan nilai-nilai atribut atau atribut tertentu, berisi kesalahan atau nilai-nilai outlier yang menyimpang dari yang diharapkan dan ketidakcocokan dalam penggunaan kode atau nama.

Disini kualitas data yang baik berbanding lurus dengan keputusan yang baik. Untuk memiliki keputusan yang baik, digunakan cara yaitu : Menghilangkan data yang salah, memperbaiki kekacauan data dan memeriksa data yang tidak konsisten yang disebut dengan data Cleaning. Menggabungkan dari dari beberapa sumber kedalam penyimpanan data yang sesuai disebut dengan Data integration.

\section{Naïve Bayes}

Algoritma Naive Bayes merupakan salah satu algoritma yang terdapat pada teknik klasifikasi. Naive Bayes merupakan pengklasifikasian dengan metode probabilitas dan statistik yang dikemukan oleh ilmuwan Inggris Thomas Bayes, yaitu memprediksi peluang di masa depan berdasarkan pengalaman dimasa sebelumnya sehingga dikenal sebagai Teorema Bayes. Teorema tersebut dikombinasikan dengan Naive dimana diasumsikan kondisi antar atribut saling bebas. Klasifikasi Naive Bayes diasumsikan bahwa ada atau tidak ciri tertentu dari sebuah kelas tidak ada hubungannya dengan ciri dari kelas lainnya.

\section{Data Interpretation and Evaluation}

Tahap Evaluation ini merupakan tahapan pemeriksaan apakah pola yang terbentuk atau informasi yang dihasilkan memiliki keakuratan yang baik, atau jauh bertentangan dengan data yang sebelumnya. Pada tahap evaluasi ini akan digunakan metode confusion matrix sebagai metode yang akan menguji precision, recall maupun accuracy dari pola yang terbentuk. Accuracy didefinisikan sebagai tingkat kedekatan antara nilai prediksi dengan nilai aktual.Tahap ini merupakan bagian dari proses KDD yang mencakup pemeriksaan apakah pola atau informasi yang ditemukan bertentangan dengan fakta atau hipotesa yang ada sebelumnya.

\section{Metodologi Penelitian}

\section{A. Proses Data Mining}

Metodologi penelitian yang dilakukan pada pembuatan tugas akhir adalah melakukan tahapan proses data mining, yaitu data selection, preprocessing. data mining dan interpretation and evaluation. 


\section{E-Journal Teknik Informatika Vol 11, No.1 (2017) ISSN : 2301 - 8364}

1. Data Selection

Pada proses seleksi ini, dipilih dari keseluruhan data Universitas Sam Ratulangi yaitu data alumni Fakultas Teknik angkatan 2008-2012. Dari hasil seleksi akan digunakan sebanyak 1625 data alumni untuk perhitungan pada proses data mining.

2. Preprocessing

Preprocessing menggambarkan kualitas data yang baik berbanding lurus dengan keputusan yang baik. Untuk memiliki keputusan yang baik, dilakukan proses Integrasi skema sistem, data cleaning, data transformation dan data reduction. Proses tersebut dapat dijelaskan seperti dibawah ini

a. Integrasi Skema Aplikasi Sistem

Proses ini dilakukan karena perlu adanya perubahan skema struktur data dari data mentah ke data yang siap akan dilakukan proses preprocessing lebih lanjut dengan tahap cleaning.

Tabel 1. Data Sebelum Proses Integrasi

\begin{tabular}{|c|c|c|c|c|c|c|c|}
\hline Identifier & Prodi & $\begin{array}{c}\text { Sems } \\
\text { ter }\end{array}$ & $\begin{array}{c}\text { IP } \\
\text { Seme } \\
\text { ter }\end{array}$ & $\begin{array}{c}\text { IP } \\
\mathbf{K}\end{array}$ & $\begin{array}{c}\mathbf{S} \\
\mathbf{K} \\
\mathbf{S}\end{array}$ & $\begin{array}{c}\text { Lul } \\
\mathbf{u s}\end{array}$ & $\begin{array}{c}\text { Juml } \\
\mathbf{a h} \\
\text { Seme } \\
\text { ster }\end{array}$ \\
\hline $\begin{array}{c}\text { "ff69......f } \\
\text { ad000" }\end{array}$ & $\begin{array}{c}\text { "INFORMA } \\
\text { TIKA" }\end{array}$ & $\begin{array}{c}2011 \\
1\end{array}$ & 3.05 & $\begin{array}{c}3 . \\
05\end{array}$ & 19 & 1 & 11 \\
\hline $\begin{array}{c}\text { "ff69...... } \\
\text { ad000" }\end{array}$ & $\begin{array}{c}\text { "INFORMA } \\
\text { TIKA" }\end{array}$ & $\begin{array}{c}2011 \\
2\end{array}$ & 3.33 & $\begin{array}{c}3 . \\
21\end{array}$ & 24 & 1 & 11 \\
\hline $\begin{array}{c}\text { fff69......f } \\
\text { ad000" }\end{array}$ & $\begin{array}{c}\text { "INFORMA } \\
\text { TIKA" }\end{array}$ & $\begin{array}{c}2012 \\
1\end{array}$ & 3.05 & $\begin{array}{c}3 . \\
16\end{array}$ & 19 & 1 & 11 \\
\hline $\begin{array}{c}\text { "ff69......f } \\
\text { ad000" }\end{array}$ & $\begin{array}{c}\text { "INFORMA } \\
\text { TIKA" }\end{array}$ & $\begin{array}{c}2012 \\
2\end{array}$ & 3.22 & $\begin{array}{c}3 . \\
18\end{array}$ & 23 & 1 & 11 \\
\hline
\end{tabular}

Data akan berubah skema atau struktur menjadi seperti pada tabel 2 yang mudah untuk diproses. Data tabel didefinisikan memanjang ke samping kanan dengan penggunaan kolom yang lebih banyak, dikarenakan hasil pivoting dari tiap data identifier.

Tabel 2. Data Sesudah Proses Integrasi

\begin{tabular}{|c|c|c|c|c|c|c|c|c|c|c|c|}
\hline \multirow[b]{2}{*}{$\begin{array}{l}\text { Iden } \\
\text { tifier }\end{array}$} & \multirow[b]{2}{*}{$\begin{array}{c}\text { Pr } \\
\text { od } \\
\text { i }\end{array}$} & \multirow[b]{2}{*}{$\begin{array}{l}\mathbf{L} \\
\text { ul } \\
\text { us }\end{array}$} & \multirow[b]{2}{*}{$\begin{array}{c}\text { Ang } \\
\text { kat } \\
\text { an }\end{array}$} & \multicolumn{4}{|c|}{ IP Semester } & \multicolumn{4}{|c|}{ SKS } \\
\hline & & & & $\begin{array}{c}20 \\
11 \\
1\end{array}$ & $\begin{array}{c}20 \\
11 \\
2\end{array}$ & $\begin{array}{c}20 \\
12 \\
1\end{array}$ & $\begin{array}{c}20 \\
12 \\
2\end{array}$ & $\begin{array}{c}20 \\
11 \\
1\end{array}$ & $\begin{array}{c}20 \\
11 \\
2\end{array}$ & $\begin{array}{c}20 \\
12 \\
1\end{array}$ & $\begin{array}{c}20 \\
12 \\
2\end{array}$ \\
\hline "ff6" & IT & 1 & $\begin{array}{c}201 \\
1\end{array}$ & $\begin{array}{l}3 . \\
05\end{array}$ & $\begin{array}{l}3 . \\
33\end{array}$ & $\begin{array}{l}3 . \\
05\end{array}$ & $\begin{array}{l}3 . \\
22\end{array}$ & 19 & 24 & 19 & 23 \\
\hline
\end{tabular}

Pada proses ini data yang tidak perlu dipakai pada penggunaan pengolahan data dan data yang akan menyebabkan kekacauan data sehingga data menyimpang atau tidak konsisten.

Tabel 3.Data Sebelum Proses Cleaning

\begin{tabular}{|c|c|c|c|c|c|c|c|}
\hline $\begin{array}{l}\text { Identifi } \\
\text { er }\end{array}$ & Prodi & Semster & & IPK & SKS & $\begin{array}{l}\text { Lulu } \\
\text { s }\end{array}$ & $\begin{array}{l}\mathbf{J} \\
\mathbf{S}\end{array}$ \\
\hline 11021 & "TEKNIK & 2011 & 3.2 & 3.2 & 19 & 0 & 21 \\
\hline 5 & ELEKTRO" & 1 & & & & & \\
\hline 11021 & "TEKNIK & 2011 & 3.1 & 3.1 & 20 & 0 & 21 \\
\hline 5 & ELEKTRO" & 2 & & & & & \\
\hline 11021 & "TEKNIK & 2011 & 0 & 3.1 & 0 & 0 & 21 \\
\hline 5 & ELEKTRO" & 3 & & & & & \\
\hline 11021 & "TEKNIK & 2011 & 0 & 3.1 & 0 & 0 & 21 \\
\hline 5 & ELEKTRO" & 4 & & & & & \\
\hline
\end{tabular}

Data yang akan dihapus adalah data Index Prestasi (ip) semester mahasiswa yang memiliki atau mengikuti semester perbaikan. Angka terakhir pada kolom semester menjelaskan posisi semester mahasiswa.Angka paling akhir yaitu 1 atau 2, menjelaskan ganji atau genap data semester mahasiswa.Sedangkan angka 3 atau empat adalah baris data ip semester mahasiswa yang mengikuti semester perbaikan.

c. Data Transformation

Proses Tranformation melakukan pencarian fitur yang dapat mempresentasikan data dan pencariannya sangat bergantung pada jenis atau pola informasi yang akan dicari dalam database.

Tabel 4.Transformasi Status Kelulusan

\begin{tabular}{|c|c|}
\hline Jumlah Semester & Status Kelulusan \\
\hline$<=10$ & Tepat \\
\hline$>10$ & Terlambat \\
\hline Tidak lulus & Tidak Lulus \\
\hline
\end{tabular}

Transformasi data yang terjadi pada data jumlah semester untuk menentukan status kelulusan dengan cara, Kategori status kelulusan yang akan dibagi ditentukan berdasarkan data mahasiswa yang lulus dan tidak lulus.

\section{d. Nä̈ve Bayes}

Simulasi perhitungan ini diambil 20 sampel dari data training untuk dilakukan proses mining dengan menggunakan Microsoft excel. Untuk perhitungan secara lengkap akan menggunakan bahasa pemrograman PHP.

Tabel 5. 20 Sampel Data yang akan dikelola dengan perhitungan manual

\begin{tabular}{|c|c|c|c|c|c|c|c|c|c|}
\hline $\begin{array}{l}\text { I } \\
\text { d }\end{array}$ & $\begin{array}{l}\text { An } \\
\text { gkt }\end{array}$ & Prodi & Lulus & $\begin{array}{r}\text { ips } \\
-1\end{array}$ & $\begin{array}{l}\text { ips } \\
22\end{array}$ & ….. & $\begin{array}{l}\text { sk } \\
s_{-} \\
4\end{array}$ & $\begin{array}{l}\text { sk } \\
s_{-} \\
5\end{array}$ & $\begin{array}{l}\text { sk } \\
s_{-} \\
\mathbf{6}^{\prime}\end{array}$ \\
\hline $\begin{array}{l}1 \\
2\end{array}$ & $\begin{array}{r}200 \\
9\end{array}$ & $\begin{array}{l}\text { TEKNIK } \\
\text { MESIN }\end{array}$ & Cepat & 0 & $\begin{array}{r}2.1 \\
3\end{array}$ & $\begin{array}{l}\cdots \cdots \\
\cdots \cdots . .\end{array}$ & 30 & 0 & $\mathbb{I N}$ \\
\hline $\begin{array}{l}1 \\
3\end{array}$ & $\begin{array}{r}200 \\
9\end{array}$ & $\begin{array}{l}\text { ARSITE } \\
\text { KTUR }\end{array}$ & Cepat & 4 & 0 & $\begin{array}{l}\cdots \cdots \\
\cdots \cdots \cdots\end{array}$ & 8 & IN & $\mathbb{N}$ \\
\hline $\begin{array}{l}1 \\
4\end{array}$ & $\begin{array}{r}200 \\
9\end{array}$ & $\begin{array}{l}\text { TEKNIK } \\
\text { SIPIL }\end{array}$ & Cepat & 0 & $\begin{array}{r}2.9 \\
7\end{array}$ & $\begin{array}{l}\ldots \ldots . \\
\ldots \ldots .\end{array}$ & 0 & IN & IN \\
\hline $\begin{array}{l}\cdots \\
.\end{array}$ & & & & & & $\begin{array}{l}\ldots \ldots . . \\
\ldots \ldots .\end{array}$ & & & \\
\hline $\begin{array}{l}1 \\
5\end{array}$ & $\begin{array}{r}201 \\
0\end{array}$ & $\begin{array}{l}\text { TEKNIK } \\
\text { SIPIL }\end{array}$ & Cepat & 4 & $\begin{array}{r}2.7 \\
9\end{array}$ & $\begin{array}{l}\cdots \ldots . \\
\ldots \ldots . .\end{array}$ & 10 & 34 & 24 \\
\hline $\begin{array}{l}2 \\
9\end{array}$ & $\begin{array}{r}201 \\
0\end{array}$ & $\begin{array}{l}\text { INFORM } \\
\text { ATIKA }\end{array}$ & $\begin{array}{l}\text { Tidak } \\
\text { Lulus }\end{array}$ & $\begin{array}{r}2.5 \\
6\end{array}$ & $\begin{array}{r}2.8 \\
5\end{array}$ & $\begin{array}{l}\ldots \ldots . . \\
\ldots \ldots . .\end{array}$ & 18 & 17 & 17 \\
\hline $\begin{array}{l}3 \\
0\end{array}$ & $\begin{array}{r}201 \\
0\end{array}$ & $\begin{array}{l}\text { ARSITE } \\
\text { KTUR }\end{array}$ & $\begin{array}{l}\text { Tidak } \\
\text { Lulus }\end{array}$ & 1.8 & 0.5 & $\begin{array}{l}\cdots \cdots \\
\ldots \ldots . .\end{array}$ & 17 & 16 & 15 \\
\hline $\begin{array}{l}3 \\
1\end{array}$ & $\begin{array}{r}201 \\
0\end{array}$ & $\begin{array}{l}\text { TEKNIK } \\
\text { SIPIL }\end{array}$ & $\begin{array}{l}\text { Tidak } \\
\text { Lulus }\end{array}$ & $\begin{array}{r}0.7 \\
3\end{array}$ & $\begin{array}{r}2.3 \\
8\end{array}$ & $\begin{array}{l}\ldots \ldots . . \\
\ldots \ldots . .\end{array}$ & 15 & 20 & 17 \\
\hline
\end{tabular}

\section{Menghitung Standar Deviasi dan Mean}

Nilai Standar Deviasi dan Mean diambil dari masing - masing variable yang bernilai kontinu antara lain IPS_1, IPS_2, IPS_3, IPS_4, IPS_5, IPS_6, SKS_1, SKS_2, SKS_3, SKS_4, SKS_5, dan SKS_6 pada setiap kategori. Berikut proses perhitungan yang menunjukan nilai Mean dan Standar Deviasi. 
E-Journal Teknik Informatika Vol 11, No.1 (2017) ISSN : 2301 - 8364

Tabel 7.Perhitungan Mean dan Standar Deviasi pada IP dan SKS dalam semester $1 \mathrm{~s} / \mathrm{d} 6$

\begin{tabular}{|c|c|c|c|c|c|c|}
\hline kelas & Mean/sttde & ips_1 & ips_2 & ipk_4 & ipk_5 & ipk_6 \\
\hline \multirow{2}{*}{ cepat } & Mean & 2.186 & 2.122 & 15.6 & 6.8 & 4.8 \\
\hline & $\begin{array}{l}\text { Standar } \\
\text { Deviasi }\end{array}$ & $\begin{array}{c}2.042 \\
787\end{array}$ & $\begin{array}{c}1.227 \\
383\end{array}$ & $\begin{array}{c}13.66 \\
748\end{array}$ & $\begin{array}{c}15.20 \\
526\end{array}$ & $\begin{array}{c}10.73 \\
313\end{array}$ \\
\hline \multirow{2}{*}{ tepat } & Mean & 3.39 & 3.032 & 15.8 & 23.8 & 22.2 \\
\hline & $\begin{array}{l}\text { Standar } \\
\text { Deviasi }\end{array}$ & $\begin{array}{c}0.601 \\
457\end{array}$ & $\begin{array}{c}0.693 \\
376\end{array}$ & $\begin{array}{c}9.038 \\
805\end{array}$ & $\begin{array}{c}2.489 \\
98\end{array}$ & $\begin{array}{c}4.969 \\
909\end{array}$ \\
\hline \multirow{2}{*}{$\begin{array}{l}\text { terlam } \\
\text { bat }\end{array}$} & Mean & 1.51 & 2.198 & 15.4 & 19.8 & 21 \\
\hline & $\begin{array}{l}\text { Standar } \\
\text { Deviasi }\end{array}$ & $\begin{array}{c}1.465 \\
06\end{array}$ & $\begin{array}{c}1.691 \\
544\end{array}$ & $\begin{array}{c}8.619 \\
745\end{array}$ & $\begin{array}{c}0.447 \\
214\end{array}$ & $\begin{array}{c}4.301 \\
163\end{array}$ \\
\hline \multirow{2}{*}{$\begin{array}{l}\text { tidak } \\
\text { lulus }\end{array}$} & Mean & 1.246 & 0.908 & 14.2 & 15.2 & 16 \\
\hline & $\begin{array}{l}\text { Standar } \\
\text { Deviasi }\end{array}$ & $\begin{array}{c}1.154 \\
807\end{array}$ & $\begin{array}{c}1.243 \\
411\end{array}$ & $\begin{array}{c}8.043 \\
631\end{array}$ & $\begin{array}{c}8.584 \\
87\end{array}$ & $\begin{array}{c}9.192 \\
388\end{array}$ \\
\hline
\end{tabular}

Dengan aturan tersebut jika diberikan data baru yang terdapat pada tabel di bawah ini maka prediksi masa studi mahasiswa dapat dikategorikan dengan menggunakan langkah-langkah sebagai berikut :

Tabel 8.Data hitung manual

\begin{tabular}{|c|c|c|c|c|c|c|c|}
\hline NIM & Prodi & IPS1 & IPS2 &.. & SKS3 & SKS4 & SKS5 \\
\hline 12345 & Sipil & 2.52 & 2.98 &.. & 19 & 9 & 14 \\
\hline
\end{tabular}

2. Menghitung Probabilitas untuk setiap kelas berdasarkan fitur

Dari kasus diatas maka akan dilakukan perhitungan nilai probabilitas dari variabel yang bersifat kontinu yaitu IPS1 s/d IPS6. Berikut proses perhitungan masing-masing IPS :

a. Probabilitas IPS dan SKS untuk kelas Tepat dari IPS1 s/d IPS6

1) Probabilitas IPS1 untuk kelas Tepat

Standar Deviasi $\sigma=$ 0.601456565347825

Mean $\quad \mu=3.39$

$\mathrm{f}(\mathrm{ips} 1=2.52 \mid$ Tepat $) \quad=$

$\frac{1}{\sqrt{2 \pi(0.601456565347825)}} e^{\frac{(2.52-3.39)^{2}}{2(0.601456565347825)^{2}}}$

$=0.216730648 \times 2,7183^{-0.20084401}$

$=0.177294107$

2) Probabilitas IPS2 untuk kelas Tepat

Standar Deviasi $\sigma=$

0.693375799981511

Mean $\quad \mu=3.032$

$\mathrm{f}(\mathrm{ips} 2=2.98 \mid$ Tepat $) \quad=$

$\frac{1}{\sqrt{2 \pi(0.693375799981511)}} e^{\frac{(2.98-3.032)^{2}}{2(0.693375799981511)^{2}}}$
$=0.22917 \times 2,7183^{-0.5947}$
$=0.12644$

b. Probabilitas IPS dan SKS untuk kelas

Terlambat dari IPS1 s/d IPS6

1) Probabilitas IPS1 untuk kelas Terlambat Standar Deviasi $\sigma=1.46506$

Mean $\quad \mu=1.51$

f(ips1 = 2.52 | Tepat)

$=\frac{1}{\sqrt{2 \pi(1.46506)}} e^{\frac{(2.52-1.51)^{2}}{2(1.46506)^{2}}}$

$=0.329679933 \times 2,7183^{-0.009160196}$
$=0.32667377$

3. Membandingkan hasil perkalian ketiap kelas

$\begin{array}{ll}\text { - } & \text { Likelihood Cepat } \quad: \\ \quad \mathrm{P}(\text { Sipil|Cepat }) * \mathrm{P}(\mathrm{IPS} 1 \mid \text { Cepat }) * \mathrm{P}(\mathrm{IPS} 2 \mid \mathrm{C}\end{array}$

epat)*P(IPS3|Cepat)*P(IPS

$4 \mid$ Cepat $) * \mathrm{P}(\mathrm{IPS} 5 \mid$ Cepat $) * \mathrm{P}(\mathrm{SKS} 1 \mid$ Cepat $)$

*P(SKS2|Cepat)*P(SKS3|Cepat)*P(SK

S4|Cepat)*P(SKS5|Cepat)

$=0.4 * 0.27549 * 0.28211 * 0.22815 *$

$0.30901 * 0.31946 * 0.08218 * 0.06121$

$* 0.06275 * 0.09606 * 0.09148$

$=0.954276465$

- Likelihood Tepat

$=2.81285 \mathrm{E}-05$

- Likelihood Terlambat

$=0$

- $\quad$ Likelihood Tidak Lulus

$=0.045695407$

$\begin{array}{ll}\text { Probabilitas of Cepat } & =82 \% \\ \text { Probabilitas of Tepat } & =13 \% \\ \text { Probabilitas of Terlambat } & =0 \% \\ \text { Probabilitas of Tidak Lulus } & =5 \%\end{array}$

Dari contoh kasus di atas bisa diprediksi bahwa mahasiswa dengan Program Studi Teknik Sipil, dengan data IP Semester 1 s/d 5 memiliki Hasil Prediksi $=$ Cepat

B. Pemodelan Proses Sistem

Pemodelan proses pada penelitian ini dilakukan dengan menggunakan Data Flow Diagram (DFD). DFD adalah diagram yang menggambarkan aliran data melalui sistem dan kerja atau pengelolahan yang dilakukan oleh sistem tersebut.

1. Diagram Konteks

Diagram konteks adalah diagram yang mnampilkan gambaran keseluruhan sistem. Gambar 1 dapat dilihat gambaran sistem yang akan dibuat memiliki dua aktor yaitu Admin (Penguji/Pengolah data) dan User (Dosen).

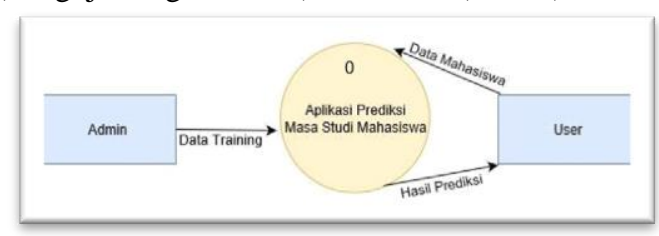

Gambar 1. Diagram Konteks

2. DFD Level 0

Diagram Nol bertujuan untuk menggambarkan proses aliran data secara terperinci yang ada pada suatu sistem. Diagram Nol merupakan tingkat lanjutan dari diagram konteks. Gambar.2 menjelaskan secara rinci bagaimana proses prediksi masa studi mahasiswa bekerja. 
E-Journal Teknik Informatika Vol 11, No.1 (2017) ISSN : 2301 - 8364

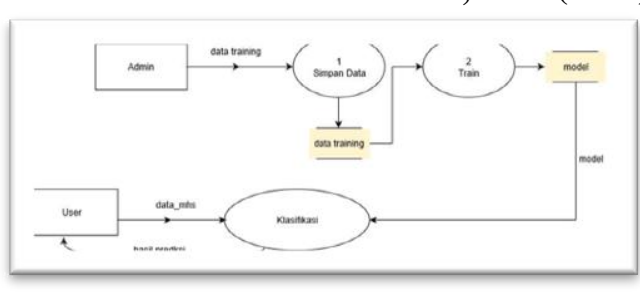

Gambar 2. DFD Level 0

3. DFD Level 1 Preprocessing Data Training

Pada proses preprocessing data training terdapat proses dimana data training yang dimasukan oleh aktor admin sebelum disimpan pada storage harus melalui proses transformasi terlebih dahulu. Dimana data mentah dari user diubah menjadi data yang dapat dikelola oleh sistem. Diagram dijelaskan pada Gambar 3.

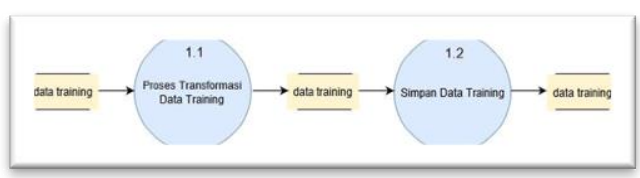

Gambar 3. Diagram Level 1 Preprocessing Data Training

\section{IV.HASIL DAN PEMBAHASAN}

A. Interface Sistem

1. Halaman Utama Sistem

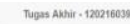

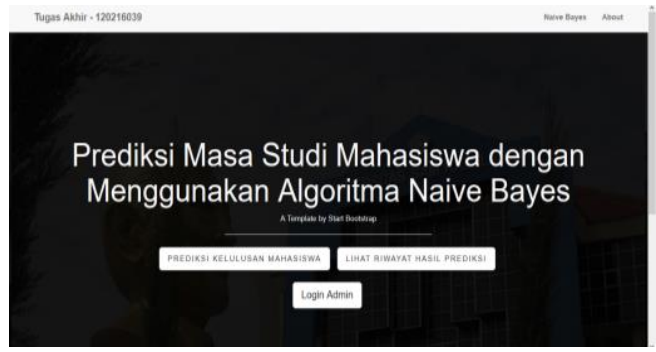

Gambar 4. Tampilan Halaman Utama Sistem

Gambar 4 adalah Tampilan pada halaman awal yang menampilkan tiga menu utama pada bagian tengah tampilan halaman, serta ada menu tambahan pada bagian kanan atas halaman web

2. Halaman Utama Admin

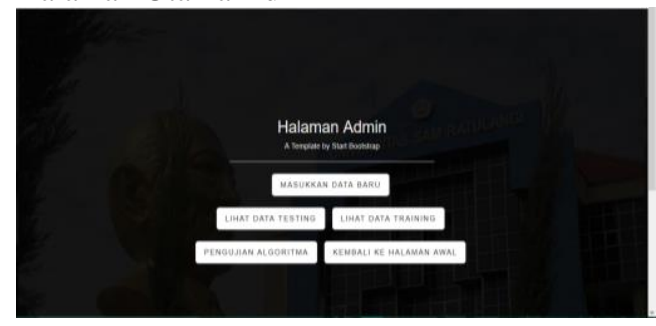

Gambar 5. Tampilan Halaman Utama Admin Halaman ini berisi beberapa menu yang digunakan untuk mengaskses menu - menu seperti pada gambar 5 diatas
3. Halaman Prediksi di Semester

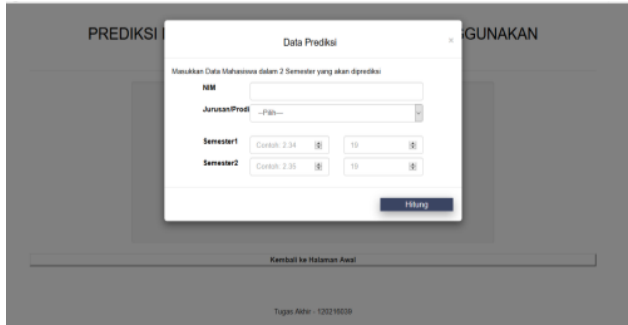

Gambar 6. Tampilan Halaman

Prediksi di Semester

Gambar 6 ini menampilkan format isian data prediksi mahasiswa di semester dimana mahasiswa sedang menjalankan atau baru selesai perkuliahan.Isian yang ada berupa NIM, Jurusan atau Program Studi dan IP Semester serta SKS yang disesuaikan dengan semester mahasiswa.

4. Halaman Hasil Prediksi

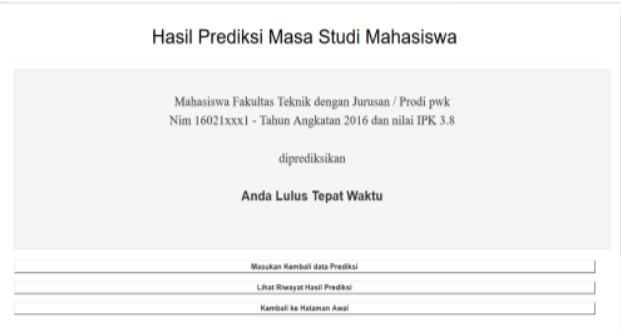

Gambar 7. Tampilan Halaman Hasil Prediksi

Gambar 7 adalah halaman hasil prediksi yang akan langsung keluar setelah data mahasiswa dimasukan untuk dilakukan prediksi. Hasil prediksi ini berupa kesimpulan status kelulusan mahasiswa yang diiput untuk dilakukan prediksi.

\section{B. Pengujian Model}

Pengujian Model ini merupakan pengujian data terhadap algoritma.Metode pengujian yang dipakai adalah Pengujian Cross_Validation 10-Fold yang diambil dan diuji pada bagian jumlah semester yang dilakukan prediksi.

Total Perhitungan pengujian ini yaitu dengan membagi total data umenjadi 10 bagian sama banyak. Proses pertama yang dilakukan yaitu mengambil bagian pertama menjadi data uji (data testing) dan dilakukan perhitungan akurasi berdasarkan data pada kelompok bagian tersebut. Sementara data yang lain (selain bagian pertama) menjadi data latih (data training).

1. Model untuk Confusion Matrix Dua Semester

Tabel 9. Confusion Matrix Dua Semester

\begin{tabular}{|c|c|c|c|c|}
\hline & \multicolumn{3}{|c|}{ Data Alumni } \\
\hline & & Tepat & Terlambat & Tidak Lulus \\
\hline \multirow{3}{*}{ Data Prediksi } & Tepat & 63 & 250 & 42 \\
\hline & Terlambat & 15 & 413 & 133 \\
\hline & Tidak Lulus & 4 & 155 & 550 \\
\hline \multicolumn{5}{|c|}{ Total Data : 1625} \\
\hline
\end{tabular}




\section{E-Journal Teknik Informatika Vol 11, No.1 (2017) ISSN : 2301 - 8364}

Untuk pengujian dua semester, jumlah data prediksi dengan data alumni di tampilkan dalam bentuk Confusion Matrix. Dalam proses pengujian ini didapatkan akurasi data sebesar $63.14 \%$

2. Model untuk Confusion Matrix Tiga Semester

Tabel 10.Confusion Matrix Tiga Semester

\begin{tabular}{|l|l|l|l|l|}
\hline \multicolumn{2}{|c|}{} & \multicolumn{3}{|c|}{ Data Alumni } \\
\cline { 3 - 5 } & Tepat & Terlambat & Tidak Lulus \\
\hline \multirow{3}{*}{ Data Prediksi } & Tepat & 55 & 191 & 16 \\
\cline { 2 - 5 } & Terlambat & 25 & 563 & 65 \\
\cline { 2 - 5 } & Tidak Lulus & 2 & 64 & 644 \\
\hline \multicolumn{3}{|c|}{ Total Data : 1625} & $=77.66 \%$
\end{tabular}

Untuk pengujian empat semester, jumlah data prediksi dengan data alumni di tampilkan dalam bentuk Confusion Matrix.Dalam proses pengujian ini didapatkan akurasi data sebesar $77.66 \%$

3. Model untuk Confusion Matrix Empat Semester

Tabel 11.Confusion Matrix Empat Semester

\begin{tabular}{|l|l|l|l|l|}
\hline \multirow{2}{*}{} & \multicolumn{3}{|l|}{ Data Alumni } \\
\cline { 3 - 5 } & Tepat & Terlambat & Tidak Lulus \\
\hline \multirow{3}{*}{ Data Prediksi } & Tepat & 66 & 205 & 0 \\
\cline { 2 - 5 } & Terlambat & 15 & 580 & 34 \\
\cline { 2 - 5 } & Tidak Lulus & 1 & 33 & 691 \\
\hline \multicolumn{4}{|l|}{ Total Data : 1625} &
\end{tabular}

$$
\text { Akurasi }=\frac{66+580+691}{1625} * 100 \quad=82.27 \%
$$

Untuk pengujian tiga semester, jumlah data prediksi dengan data alumni di tampilkan dalam bentuk Confusion Matrix.Dalam proses pengujian ini didapatkan akurasi data sebesar $82.27 \%$

4. Model untuk Confusion Matrix Lima Semester

Tabel 12.Confusion Matrix Lima Semester

\begin{tabular}{|l|l|l|l|l|}
\hline \multicolumn{2}{|c|}{} & \multicolumn{3}{|l|}{ Data Alumni } \\
\cline { 3 - 5 } \multicolumn{2}{|c|}{} & Tepat & Terlambat & Tidak Lulus \\
\hline \multirow{3}{*}{ Data Prediksi } & Tepat & 74 & 147 & 3 \\
\cline { 2 - 5 } & Terlambat & 8 & 631 & 43 \\
\cline { 2 - 5 } & Tidak Lulus & 0 & 40 & 679 \\
\hline Total Data : 1625 & \multicolumn{3}{|c}{$=85.17 \%$}
\end{tabular}

Untuk pengujian lima semester, jumlah data prediksi dengan data alumni di tampilkan dalam bentuk Confusion Matrix. Dalam proses pengujian ini didapatkan akurasi data sebesar $85.17 \%$

Tabel 13. Perbandingan Akurasi Semester

\begin{tabular}{|l|l|l|l|l|}
\hline $\begin{array}{l}\text { Pengujian } \\
\text { ke - }\end{array}$ & $\begin{array}{l}\text { Dua } \\
\text { Semester }\end{array}$ & $\begin{array}{l}\text { Tiga } \\
\text { Semester }\end{array}$ & $\begin{array}{l}\text { Empat } \\
\text { Semester }\end{array}$ & $\begin{array}{l}\text { Lima } \\
\text { Semester }\end{array}$ \\
\hline 1 & $60.74 \%$ & $79.75 \%$ & $83.43 \%$ & $87.12 \%$ \\
\hline 2 & $66.87 \%$ & $79.14 \%$ & $84.04 \%$ & $88.96 \%$ \\
\hline 3 & $61.96 \%$ & $74.23 \%$ & $81.59 \%$ & $85.27 \%$ \\
\hline 4 & $63.80 \%$ & $79.75 \%$ & $81.59 \%$ & $82.21 \%$ \\
\hline 5 & $62.58 \%$ & $76.07 \%$ & $79.14 \%$ & $80.98 \%$ \\
\hline 6 & $62.34 \%$ & $74.69 \%$ & $82.09 \%$ & $85.18 \%$ \\
\hline 7 & $58.02 \%$ & $75.92 \%$ & $79.62 \%$ & $82.72 \%$ \\
\hline 8 & $67.90 \%$ & $74.69 \%$ & $77.77 \%$ & $84.58 \%$ \\
\hline 9 & $63.58 \%$ & $83.33 \%$ & $85.80 \%$ & $87.65 \%$ \\
\hline 10 & $63.58 \%$ & $79.01 \%$ & $87.65 \%$ & $87.04 \%$ \\
\hline & $63.14 \%$ & $77.66 \%$ & $82.27 \%$ & $85.17 \%$ \\
\hline
\end{tabular}

Tabel perbandingan akurasi di tiap semester merupakan data yang membandingkan antara data dua semester hingga lima semester. Pengujian ini dilakukan berulang kali berdasarkan 10 kelompok pembagian yang digunakan dalam proses pengujian. Dari tabel hasil perbandingan, perhitungan akurasi dengan nilai rata-rata ditiap kelompok pada limasemester yaitu $85.17 \%$ memiliki nilai tertinggi.

\section{PENUTUP}

A. Kesimpulan

Masa studi mahasiswa dapat diprediksi berdasarkan faktor yang berkaitan dengan akademik mahasiswa, seperti program studi, nilai ip semester dan jumlah sks saat di perguruan tinggi.Algoritma Nä̈ve Bayes yang dipakai dapat menentukan prediksi masa studi mahasiswa dengan tingkat Akurasi pada pengujian algoritma bernilai $85.17 \%$ pada nilai ratarata pengujian di lima semester.

B. Saran

Pada prediksi masa studi mahasiswa ini dapat ditambahkan fitur - fitur yang bernilai dan faktor diluar akademik mahasiswa (eksternal) untuk dapat menjadi salah satu faktor penentu lama masa studi.

Dapat dilakukan uji coba menggunakan algoritma lain dan hasilnya dapat dilakukan perbandingan dan analisa untuk pengembangan penelitian kedepan.Pada Penelitian ini dapat memperbaiki kualitas data lebih baik agar mendapatkan hasil klasifikasi yang baik.Dalam proses data mining seharusnya dilakukan proses cleaning data, integrasi data, transformasi data, aplikasi data mining dab evaluasi pola yang ditemukan dalam data mining agar menghasilkan nilai keakuratan yang baik.

\section{DAFTAR REFERENSI}

[1] Larose, D. (2005). Discovering Knowledge In Data. Canada: Willey Interscience. metodealgoritma.com. (2013, Maret 27).

[2] Hoffer, Ramesh and Topi. (2012). Modern Database Management. Harlow United Kingdom : Pearson Education Limited.

[3] MacLennan, J., Zhao Hui Tang, Bog, Crivat, "Data Mining with Microsoft ${ }^{\circledR}$ SQL Server ${ }^{\circledR}$ 2008", Wiley Publishing, Inc., Indianapolis, Indiana. 2009.

[4] Prasetyo, Eko. 2012. Data Mining Konsep dan Aplikasi Menggunakan MATLAB. Yogyakarta: Andi 


\section{SEKILAS TENTANG PENULIS}

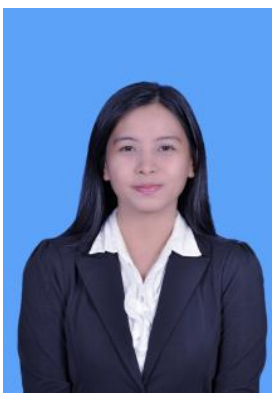

Saya bernama Mongan Winny Amelia dan merupakan anak kedua dari pasangan Satyano W. Mongan dan Jenny N. Sege, lahir di Manado pada tanggal 15 Juli1994. Asal daerah Manado.

Saya mulai menempuh pendidikan di sekolah dasar SDN Malalayang (2000 - 2006). Kemudian melanjutkan studi tingkat pertama di SMPN 8Manado (2006 - 2009) dan selanjutnya saya menempuh pendidikan tingkat atas di SMAN 1Manado (2009- 2012).

Setelah itu, di tahun 2012 saya melanjutkan pendidikan ke salah satu perguruan tinggi yang berada di Manado yaitu Universitas Sam Ratulangi Manado, dengan mengambil Program Studi S-1 Teknik Informatika di Jurusan Elektro Fakultas Teknik. 